\title{
Socio-economic Traits Influencing the Income of Farm Women Earning Livelihood through Livestock Enterprises in Goalpara District of Assam, India
}

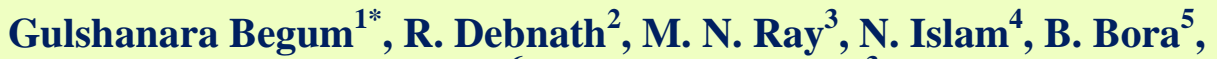 \\ N. K. $\operatorname{Roy}^{6}$ and Deepjyoti $\operatorname{Roy}^{3}$ \\ ${ }^{1}$ Department of Economics, Lakhipur College, P.O. Lakhipur, Goalpara, Kokrajhar \\ Commerce College, P.O. Kokrajhar, BTC Kokrajhar, Assam, India \\ ${ }^{2}$ Department of Extension Education, ${ }^{6}$ Department of LPM, CVSc. AAU, Khanapara, \\ PIN-781022, Assam, India \\ ${ }^{3}$ Department Govt. of Assam, P.O. Baida, Goalpara, Assam, India \\ ${ }^{4}$ Department of Extension Education, ${ }^{5}$ Department of Extension Education, LCVSc. AAU, \\ Joyhing Road, North Lakhimpur, PIN-787051, Assam, India \\ *Corresponding author
}

\section{A B S T R A C T}

The aim of this study was to study the Socio-economic traits influencing the income of

\section{Keywords}

Word, Socioeconomic traits, Farm women, Livelihood, Livestockenterprises

Article Info

Accepted:

18 July 2020 Available Online: 10 August 2020 farm women earning livelihood through livestock enterprises in Goalpara district of Assam. Ten tribal dominated villages and ten non-tribal dominated villages were selected at random basis in 20 selected villages. Twenty percent of farm women who had at least one milch cattle, and/or two small animals like sheep, goat or pig and/or 20 numbers of poultry (duck or fowl) were selected at random from each of the tribal and non-tribal dominated villages to make the sample size 350 (50\% from each of tribal and non-tribal groups). It was found that tribal women's education and their mass media exposure had positive significant relationship with egg production. These two variables were the motivating factors for augmenting egg production. The non-tribal women's land holding and knowledge in improved animal husbandry exhibited positive significant relation with egg production. Pooled data revealed that participation in 'decision making in livestock management and marketing' had significant positive relation with egg production. It was concluded that the tribal women's level of family education, extension contact, and their level of participation in decision making in livestock management were positively correlated with income from livestock. Similarly in non-tribal women mass media exposure, extension contact and knowledge in improved animal husbandry had positive correlation with income from livestock enterprise.

\section{Introduction}

Contribution of women in animal husbandry is not new and they play an active role in performing many important tasks like rearing and management, health care, hygiene and sanitation in farm houses and also in selling food products of animal origin. Farm women provide economic support of the families and generation of income for the livelihood of the 
family members. In recent years entrepreneurship has gained popularity around the globe and women are also coming forward to take part in it in different sector including livestock in order to make them empowered socially, economically and psychologically.

The role of women in livestock related activities is a subject of interest for social scientists and also for planners and policy makers (Patel et al., 2016). In Goalpara district of Assam, where livestock farming is an important part of the mixed crop farming system, women in rural areas actively participate and undertake all operations like rearing, management, health coverage, marketing of food of animal origin etc.

The main components of livestock farming system in this district are cattle, buffalo, pig, sheep, goat and poultry including duck and fowl (Pegu, 2019). The human population of the area is constituted by people of different religions and ethnic groups (FAO, 2002). Guèye (2003) stated that, livestock keeping is usually the responsibility of both women and men.

Unfortunately, there is a lack of awareness of women's and men's specic roles in livestock production, this result in 'gender blindness'. Hence, women's contribution to this subsistence livestock sub-sector remains 'invisible' because it is usually not quantitatively or qualitatively assessed.

Therefore the present study was undertaken with the following two objectives includes to find out the influence of socio-economic traits of farm women in their income derived from livestock enterprise. And also to explore the differences between tribal and non-tribal farm women in respect of their socio-economic traits having significant influence on their income from livestock enterprises.

\section{Materials and Methods}

The Goalpara district of Assam was the study area where a comprehensive list of villages was prepared block wise. Considering the demographic profile as revealed in some secondary source, the tribal and non-tribal dominated villages were identified. Ten tribal dominated villages and ten non-tribal dominated villages were selected at random. In each of these 20 selected villages lists of livestock women farmers were prepared in consultation with the local veterinary officers.

A farm woman having at least one milch cattle, and/or two small animals like sheep, goat or pig and/or 20 numbers of poultry (duck or fowl) was considered eligible as respondent of the study. Twenty percent of such farm women were selected at random from each of the tribal and non-tribal dominated villages to make the sample size 350 (50\% from each of tribal and non-tribal groups). An interview schedule was prepared enlisting the socio-economic traits of the farm women and income they earned from different livestock enterprise.

This instrument was pre-tested upon 20 nonsample respondents to assess its reliability. Further its content validity was also taken into consideration. The data were personally collected by the researchers from all the respondents during March-June, 2019. Data thus collected were scrutinized, tabulated and subjected to statistical analysis like correlation and regression, etc.

\section{Results and Discussion}

Correlation of the socio-economic traits with the income of farm women from livestock enterprises

A look in Table 1 revealed that for tribal women their education and mass media exposure had positive significant relationship 
with egg production. Similarly for non-tribal women land holding and knowledge in improved animal husbandry exhibited positive significant relation with egg production. But in overall sample only the participation in 'decision making in livestock management and marketing' was found to have significant positive relation with egg production.

From the above findings it is abundantly clear that higher level of education and mass media exposure in tribal women led them to higher egg production, which was obviously due to their growing awareness about the health outcome of egg. These two variables were the motivating factors for augmenting egg production. But in non-tribal women land holding and knowledge level in improved animal husbandry had a bearing with egg production.

The positive relation of higher knowledge level in improved animal husbandry with egg production is easily understandable. But the relationship of land holding with egg production seems prime facie paradoxical. A close scrutiny might lead one to see a deeper relationship. With higher land holding the rural women might be motivated to extend their venture for undertaking some domestic birds for egg production both for domestic consumption as well as sale. This kind of apprehension was also expressed by Borah and Halim (2014) in their respective report.

Table.1 Relational Analysis of Socio-economic variables of the respondents their Egg production (Nos.)

\begin{tabular}{|l|c|c|c|}
\hline Independent Variable & \multicolumn{3}{|c|}{ "r" value } \\
\hline Age (Year) & Tribal & Non -Tribal & Pooled \\
\hline Education (self) & -0.081 & 0.070 & -0.031 \\
\hline Education (family) & $0.295^{* *}$ & 0.095 & 0.210 \\
\hline Family size & 0.106 & 0.123 & 0.103 \\
\hline $\begin{array}{l}\text { Land holding (cultivated) in } \\
\text { Bigha }\end{array}$ & -0.019 & -0.005 & -0.0122 \\
\hline $\begin{array}{l}\text { Land Holding (total) } \\
\text { Social participation }\end{array}$ & 0.133 & $0.240^{* *}$ & 0.1191 \\
\hline $\begin{array}{l}\text { Mass media exposure } \\
\text { Extension contact }\end{array}$ & 0.146 & $0.258^{* *}$ & 0.1194 \\
\hline $\begin{array}{l}\text { Decision making pattern in } \\
\text { livestock management and } \\
\text { marketing }\end{array}$ & 0.001 & 0.008 & 0.0741 \\
\hline $\begin{array}{l}\text { Knowledge level in improved } \\
\text { animal husbandry }\end{array}$ & 0.003 & 0.120 & 0.282 \\
\hline
\end{tabular}

*Significant 5percent level of probability

** Significant 1percent level of probability 
Table.2 Regression Analysis of the socio-economic variable of the respondents on their egg production

\begin{tabular}{|c|c|c|c|c|c|c|}
\hline \multirow[t]{2}{*}{ Industrial variable } & \multicolumn{2}{|c|}{ Tribal } & \multicolumn{2}{|c|}{ Non -Tribal } & \multicolumn{2}{|c|}{ Pooled } \\
\hline & b value & t value & b value & t value & b value & t value \\
\hline Age & 1.9269 & 0.19 & 1.4659 & 0.51 & -1.9475 & -0.43 \\
\hline Education (self) & 121.3544 & 0.51 & 7.0283 & 0.27 & 65.698 & 1.72 \\
\hline Family education & 8.0389 & 0.54 & 6.4898 & 0.14 & 7.2649 & 0.92 \\
\hline Family size & -48.0257 & -0.90 & -335284 & -1.62 & -347401 & -1.21 \\
\hline Land holding & -136.1667 & 1.46 & 2.4857 & 0.14 & -8.7527 & -0.28 \\
\hline $\begin{array}{l}\text { Land } \quad \text { Holding } \\
\text { (total) }\end{array}$ & 134.3707 & 1.53 & 13.5597 & 0.86 & 21.3622 & 0.79 \\
\hline Social participation & -30.6435 & 0.41 & 1.7674 & 0.11 & -4.8605 & -0.18 \\
\hline $\begin{array}{l}\text { Mass media } \\
\text { exposure }\end{array}$ & 141.771 & $3.47 * *$ & 17.5250 & 1.53 & 72.6786 & $4.12 * *$ \\
\hline Extension contact & -18.7849 & 0.50 & 0.9539 & 0.09 & -1.06955 & -0.06 \\
\hline \multirow{2}{*}{$\begin{array}{l}\text { Knowledge level in } \\
\text { improve animal } \\
\text { husbandry }\end{array}$} & -22.6628 & 0.75 & -13.1925 & $-1.98 *$ & -15.7037 & -1.38 \\
\hline & \multicolumn{2}{|c|}{$\begin{array}{c}\mathrm{R}^{2}=0.18 \\
\mathrm{~F} \text { value for } \mathrm{R}=2.33^{*}\end{array}$} & \multicolumn{2}{|c|}{$\begin{array}{c}\mathrm{R}^{2}=0.13 \\
\mathrm{~F} \text { value for } \mathrm{R}= \\
2.48 * *\end{array}$} & \multicolumn{2}{|c|}{$\begin{array}{c}\mathrm{R}^{2}=1.12 \\
\mathrm{~F} \text { value for } \mathrm{R}= \\
24.06 * *\end{array}$} \\
\hline
\end{tabular}

*Significant 5percent level of probability

** Significant 1percent level of probability

Regression of the socio-economic traits with the income of farm women from livestock enterprises

A view in Table 2 revealed that mass media exposure of the tribal women had a significant contributory effect on egg production. The coefficient of determination $\left(\mathrm{R}^{2}\right)$ was 0.18 which implied that only 18 percent of variation in egg production could be explained by these variables. The ' $F$ ' value was 2.33 which were significant. Therefore, mass media exposure was a good predictor of egg production for tribal women. Similar kind of finding was reported by Borah and Halim (2014), Baba et al(2011).

On the other hand, knowledge level in improved animal husbandry of the non-tribal women was found to have a significant contributory effect on egg production. The $\mathrm{R}^{2}$ value was 0.13 which indicated that only 13.00 percent of variation could be explained by these variables. The significant ' $F$ ' value implied that it was a good predictor of egg production for non-tribal women. However, support from the report of Guèye (2003) also could be drawn in favour of the present context where, he reported that, in Low Income Food-Deficit countries (LIFDCs), women are playing a hidden role in poultry and its egg production. He also stated that the formation of women's cooperatives, whenever possible, will facilitate their training and education with a view to enhancing their skills which ultimately help in rural poultry industry growth because knowledge level in improved animal husbandry practices is directly correlated to livestock and poultry production. 
However, in pooled data only mass media exposure had positive impact on egg production. The $\mathrm{R}^{2}$ value was 0.12 which indicated that only 12 percent of variation in egg production could explain by these variables together and their significant ' $F$ ' value indicated that mass media exposure was a good predictor of egg production. Similar finding was also endorsed by Ariyo et al., (2013).

In conclusion it can be said that participation in decision making in livestock management and marketing had significant positive relation with egg production. It was also concluded that the tribal women's level of family education, extension contact, and their level of participation in decision making in livestock management were positively correlated with income from livestock. Similarly in non-tribal women mass media exposure, extension contact and knowledge in improved animal husbandry had positive correlation with income from livestock enterprise.

\section{References}

Patel, S.J., Patel, M.D., Patel, J.H., Patel, A.S. and Gelani, R.N. 2016: Role of women gender in livestock sector: A review; Journal of Livestock Science. 7: 92-96.

Pegu, D. 2019. An overview of the livestock sector in Assam; Research Review Journal. 4 (5):1296-1299.

Borah, M. and Halim, R.A. 2014. Dynamics of Livestock and poultry sector in Assam: A critical Analysis; Economic Affairs; 59:773-782.

Baba, S.H., Wani, M.H. and Zargar, B.A. 2011. Dynamics and Sustainability of Livestock.

FAO. 2002. Some Issues Associated with the Livestock Industries of the Asia-Pacific Region

Guèye, E.F. 2003. Gender issues in family poultry production systems in lowincome food-deficit countries; American Journal of Alternative Agriculture; Volume 18 (4):185-195.

Ariyo, O.C., Ariyo, M.O., Okelola, O.E., Aasa, O.S., Awotide, O.G., Aaron, A.J., and Oni, O.B. 2013. Assessment of the role of mass media in the dissemination of agricultural technologies among farmers in Kaduna North Local Government Area of Kaduna state, Nigeria. Journal of Biology, Agriculture and Healthcare; 3(6):19-28

\section{How to cite this article:}

Gulshanara Begum, R. Debnath, M. N. Ray, N. Islam, B. Bora, N. K. Roy and Deepjyoti Roy. 2020. Socio-economic Traits Influencing the Income of Farm Women Earning Livelihood through Livestock Enterprises in Goalpara District of Assam, India. Int.J.Curr.Microbiol.App.Sci. 9(08): 1690-1694. doi: https://doi.org/10.20546/ijcmas.2020.908.194 